\title{
Pirî Reis élete és térképészeti munkássága
}

\author{
Papp-Váry Árpád
}

DOI: $10.30921 / G K .72 .2020 .2 .1$

Absztrakt: Pirî Reis Geliboluban született. Eredeti neve Muhiddin Pirî volt. Fiatalon elszegódött nagybátyja Kemal Reis hajójára és ekkor vette fel a Pirî Reis nevet. Közös hajóútjaikon térképeket készített. 1513-ban szerkesztett világtérképét 1517-ben bemutatta I. Szelim szultánnak. 1521-ben és 1526-ban két változatban elkészítette könyvét a Kitab-ı bahriyét (A hajózásról). Az elsố változat a tengerészeknek készült, a második elegáns ajándékként, amelyet 1526-ban átadott I. Szulejmán szultánnak. Akkor nyert elismertséget térképészként, amikor az isztambuli szultáni palotában 1929-ben megtalálták világtérképének Amerikát ábrázoló részletét. A munka készitéséhez Pirî 20 régi térképet használt fel, amelyek közül az egyiket Kolumbusz rajzolta, és amelyet nagybátyja, Kemal Reis 1501-ben Valenciánál szerzett meg hét spanyol hajó elfoglalásakor. A Pirî szerkesztette világtérkép a portolán térképek stílusában készült.

Abstract: Pirî Reis was born in Gelibolu. He was originally named Muhiddin Pirî. He joined young the crew of his uncle Kemal Reis, then he took the name Pirî Reis. During their travels Pirî Reis made charts around the Mediterranean Sea. He made a world map in 1513 and he showed this map to Sultan Selim I. in 1517. He composed his book Kitab-i bahriye (Book of Navigation) in two versions in 1521 and 1526. The first version was primarily aimed at sailors, the second was rather more a piece of luxury, which Pirî Reis offered as a gift to Sultan Suleiman I. in 1526. He gained fame as a cartographer when his world map showing a part of America was discovered in the Topkapi Palace in Istanbul in 1929. The map was based on some 20 older maps and charts which Pirî Reis had collected, including charts personally designed by Columbus which his uncle Kemal Reis obtained in 1501 after capturing seven Spanish ships off the coast of Valencia. The world map was made in the style of a portolan map.

Kulcsszavak: ottomán hajóhad, portolán térképek, szélrózsa, Amerika török térképe Keywords: Ottoman fleet, portolan maps, compass rose, America on an Ottoman map

Pirî Reis a Dardanellák európai partján, Geliboluban született valamikor 1465 -1470 között. Eredeti neve Muhiddin Pirî volt. Fiatalon elszegódött nagybátyja, a szultán admirálisa (tengernagy), Kemal Reis hajójára, és késôbb ott vette fel a Pirî Reis nevet. ${ }^{1}$ II. Bajazid (1481-1512) uralomra kerülésekor komoly erôfeszítéseket tett a török tengerészet (bahriye) megerôsítésére. A török hajóhad kiépítésével párhuzamosan kibontakozott a tengeri térképészet is (Zaimeche 2010). A Földközi-tenger teljes területén a hajózási uralom kiépülésével a tengeri térképészet is elhalt. Ennek az idôszaknak volt kiváló térképészeti képviselője Pirî Reis. Nagybátyja Bajazid uralomra kerülésével kegyvesztett lett. Kezdetben kalózként járta a Földközi-tengert, majd az Ibériai-félszigetról menekítette az arabokat és a zsidókat Afrikába. Ốt kísérô

\footnotetext{
„Reisz" török jelentése kapitány, azaz rangnév, mint az erdélyi gyula szó. Az újabb magyar irodalomban ezért kisbetúvel és reisz formában szerepel. Az eddig legrészletesebb könyv (Afetinan 1975) borítójának a címében Pirî nevében a reis szót kisbetúvel írja. A könyv szövegében viszont a Törökországban használt latin betús írással mindenütt a Pirî Reis alak szerepel. A tanulmány ban hivatkozott irodalomban is ez a forma olvasható. Ezért ez a forma szerepel ebben a tanulmányban is.
}

unokatestvére útjaikról feljegyzéséket és rajzokat készített. Leírta a megtett távolságokat, a kikötők méreteit, jellemezte a véderômúveket. Útjai során megtanult arabul, görögül, olaszul, spanyolul és portugálul. 1495-ben II. Bajazid szultán, Velence elleni háborújára készülve, kéri a török kalózokat, csatlakozzanak a seregéhez. Az 1499-1502 közötti Velence elleni háborúban Pirî Reis már hajóparancsnokként vett részt.

\section{A Kitab-1 bahriye (A hajózásról)²}

1511-ben meghalt a nagybátyja, ekkor Geliboluba ment - ahogy később életrajzában írja - feljegyzéseit rendezni és térképet készíteni. Térképeit az olasz és katalán hajózási térképek mintájára szerkesztette. A Földközi-tenger partjait szemléltetô bőrre rajzolt térképeit könyvbe foglalva készítette el. A Kitab-ı bahriye (azaz A tengeri ismeretek könyve, de más nyelveken gyakran

\footnotetext{
2 A könyv címe, a Kitab-1 bahriye modern török átírással szerepel. A mai törökben a második i betûn nincs pont. Ez a pont nélküli 1 betû a mély hangrendû́ i-nek felel meg. A magyarban is volt valamikor ez a hang, pl. a híd szóban. Ezért kap mély hangrendú toldalékot, pl. hidak, és nem hidek. (A lektor megjegyzése.)
}

A hajózásról címen említett) munkájának az elején van életrajzi leírása, majd a hajózási ismeretek olvashatók. Tárgyalja a navigációt, az iránytû használatát, a térképészet, a széljárások és a tengeráramlások kérdéseit. Ezt a két részt verses formában írta meg a szerzô. A kartográfiai részt, a partszakaszok, a kikötôk, a szigetek és a szorosok térképei alkotják. A könyv befejező része a térképeket kiegészítō, prózában írt hajózási, földrajzi, történelmi ismereteket tartalmaz.

A hajózási (portolán) térképek sajátsága az irányokat (lényegében a szélirányokat) mutató vonalhálózat. A vonalhálózatok egy pontból is kiindulhatnak, de mindig van egy vagy két szélrózsa is a térképeken az irányok kiinduló pontjaként. Pirî a térképein az irányrózsára illesztett díszes nyílszerú rajz mutatja az északi irányt. (1.ábra) Néha, egyszerúbb, kisebb nyíl a keleti irányt (Mekkát) is jelöli.

Könyvében Pirî Reis leírja hogy, azért rajzolja kisméretú lapokra térképeit, mert a tengeren hánykolódó, szél fújta hajón nagyobb, összehajtogatott térkép nem használható. Itt a kisebb térképek jobban segítik a hajósok munkáját. Ezt az elgondolását következetesen betartotta, csak pár esetben 


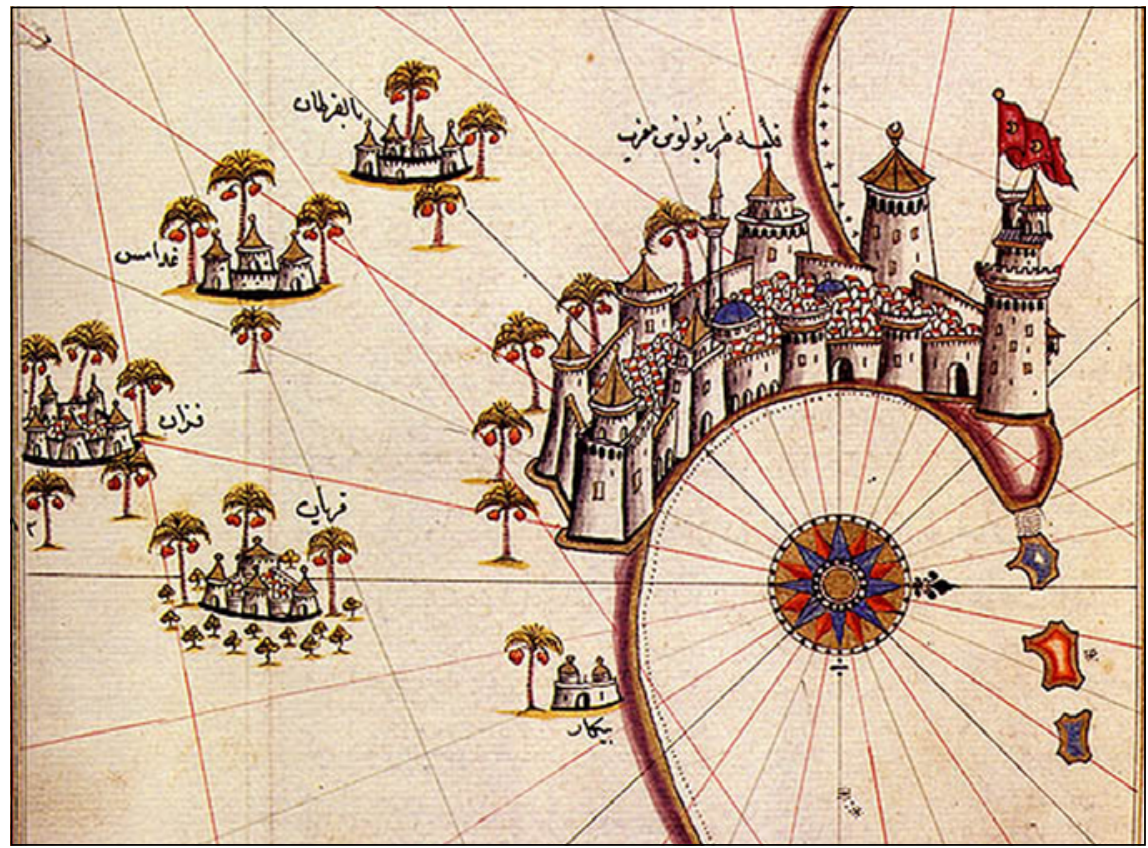

1. ábra. Szélrózsa az északi és keleti irány jelölésével (Részlet Pirî Reisz Tripolit ábrázoló térképébôl.)

készített több térképlap összeillesztésével ábrázolást. Ilyen Európa és Velence térképe. (2. ábra) A hajózásról címú könyvének készítése mellett Pirî 1513ban egy világtérképet is szerkesztett. Térképszerkesztési munkáit megszakítva, az 1516-1517 évi, Egyiptom meghódításával járó háborúban I. Szelim szultán (1512-1520) szolgálatába állt. Önéletrajzában azt írja, hogy világtérképét Kairóban átadta I. Szelim szultánnak, hangsúlyozva, hogy azon elsôként ábrázolja térképen az Indiai-óceánt és a Kínai-tengert. A szultán, állítása szerint, elismeréssel nyilatkozott a világtérképrôl (Afetinan 1975. p. 27.). A háború végén, hosszú szakaszon végighajózott a Níluson, térképezte a partvonalat és a partközeli településeket, oázisokat. Ennek eredményeként A hajózásról címú munkájában a Nílusról hat folyószakasz térképét és Alexandria és Kairó várostérképét is megjelentette. A hajózásról címú munkájának elsố változatát 1521-ben fejezte be.

1520-ban a magyar történelemből is jól ismert, késôbb Nagy jelzôvel illetett I. Szulejmán lett a szultán. Ố a sokszor sikertelenül ostromlott, a Szent János Lovagrend által birtokolt Ródosz sziget bevételére készült. A város 1522 . évi ostromában Pirî Reis is rész vett, majd hajóskapitányként Ibrahim Pasát kellett Egyiptomba szállítania. Hajózás közben gyakran elővette A hajózásról szóló munkáját, hogy felfrissítse emlékezetét. Ibrahim pasa ezt látva, javasolta hajózási jegyzeteinek kibővítését, könyvbe foglalását és átadását a szultánnak. „Kívánom ismereteit, tegye érthetôvé minden hajózó számára, és akkor ez a munkája emlékezetes marad, a világ végéig", mondta. (Afetinan 1975. p. 15.). Visszatért Geliboluba és folytatta térképszerkesztési munkáját. A Kitab-ı bahriye új változata 1526-ra készült el. Az elsố könyv tartalmát bóvítette, javította, és a térképeket a legjobb rajzolókkal és festôkkel készíttette. Ezzel a munkájával a spanyol és itáliai portolán térképkészítés hagyományát honosította meg hazájában, azaz készültek egyszerúbb kivitelú térképek a hajózok számára, tengeren való gyakorlati használatra (A hajózásról elsố kiadása ilyen), és ugyanakkor készültek csodaszép kivitelú munkák az uralkodó és a gazdag emberek könyvtárai részére (A hajózásról második kiadása ilyen). A hajózásról második kiadását Szulejmán szultánnak ajánlotta. A könyvet Ibrahim pasa közvetítésével adta át a szultánnak. „Hasonló térképmú abban az időben nem készült, ez is jelzi fontosságát ennek a munkának." (Afetinan 1975. p. 49.)

A könyv 1521. évi változatában 130, az 1526 éviben 210 térkép van. A kiadványnak mind a két változata kézírással készült. Pirî 1528-ban Geliboluban fejezte be második világtérképét, és egyesek feltételezik, ezt is be tudta mutatni Szulejmán szultánnak (Afetinan 1975 p. 58.).

Pirî Reisnek a hajózásról megjelent munkáit nagyon sokan lemásolták. A fennmaradt másolatok vizsgálata azt mutatja, nincs közöttük eredeti Pirî Reis által rajzolt munka. A könyv elsố változatából 29, a második változatból 9 maradt fenn. Továbbá három szöveg nélküli és egy csak szöveges példány is ismert (Brice - Imber 1978). A hajózásról címú munka, nagy számban fennmaradt változatai azt mutatják, hogy ezek a hajózási térképek népszerúek voltak a hajósok között, mert valósághúen

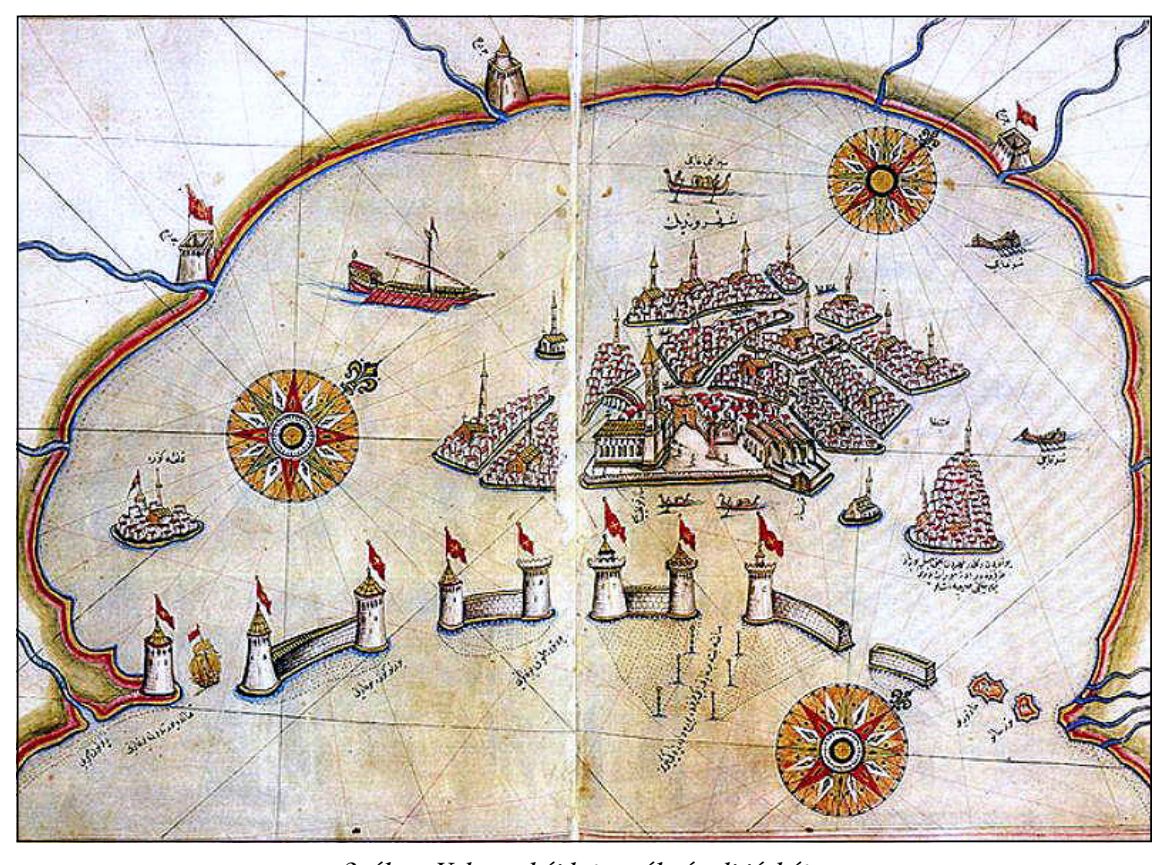

2. ábra. Velence két lapon ábrázolt térképe 
szemléltették a partokat és hasznos információkat adtak a nyílt tengeren. Bagrow szerint (1985) Pirî térképei forrásként szolgáltak több térkép készítésekor, de nem írja le, mely térképekre gondolt. A török hajósok közötti népszerúsége ellenére ezek a munkák, sem szerzőjük tevékenysége sokáig nem vált a térképtörténet részévé. Ezt a helyzetet Pirî Reis 1929-ben előkerült 1513. évi világtérképe változtatta meg.

\section{Pirî Reis Amerika-térképe}

1929-ben az isztambuli szultáni palota Nemzeti Múzeummá való átalakítási munkái során egy az ideig ismeretlen Újvilágot (Amerikát) ábrázoló őzbőrre festett térképet találtak. A térkép bal oldali ferde levágása a lefejtett őzbốr alakjából adódhat: feltételezések szerint az eredeti állat nyak és váll részét követi. A térkép felirata szerint szerzóje Pirî Reis. A $65 \times 90$ centiméter nagyságú térkép Közép- és DélAmerikát, az Ibériai-félsziget és Afrika nyugati részét ábrázolja. Kemal Atatürk, amikor tudomást szerzett a térképről, azonnal elrendelte fakszimile térképként való megjelenését török, angol, francia és német magyarázó szöveggel kiegészítve. A térkép 1935-ben jelent meg (Akçura 1935). Atatürk célja az volt a kiadással, hogy egyrészt erôsítse a törökök hazafiasságát, másrész ezzel is kitűzze az ország helyét a modern nyugati civilizációban.

A térképen nincs fokhálózat. Az Atlanti-óceán északi és déli medencéjében két 32 ágú szélrózsa van. A szélrózsák átmérôje pontosan egy mérföld. Az ágakból kiinduló irányok váltakozón piros és kék színúek. Az egész térképet behálózó szélirányok három további pontból is kiindulnak. A szélrózsák és a szélirányok rajzai jól mutatják, hogy portolán világtérképet szerkesztett Pirî Reis. A térkép aránymértékét, két változatban, az óceán közepére, a szélrózsák mellé rajzolták.

Mivel maga a szerzó is világtérképnek nevezi munkáját, ezért a fennmaradt rész alapján a kutatók megkísérelték elképzelni, hogyan nézhetett ki az eredeti munka. Alberto Cantino 1502. évi világtérképére illesztették a megmaradt darabot és a szélrózsák atlanti-óceáni körívét teljes körré egészítették ki.

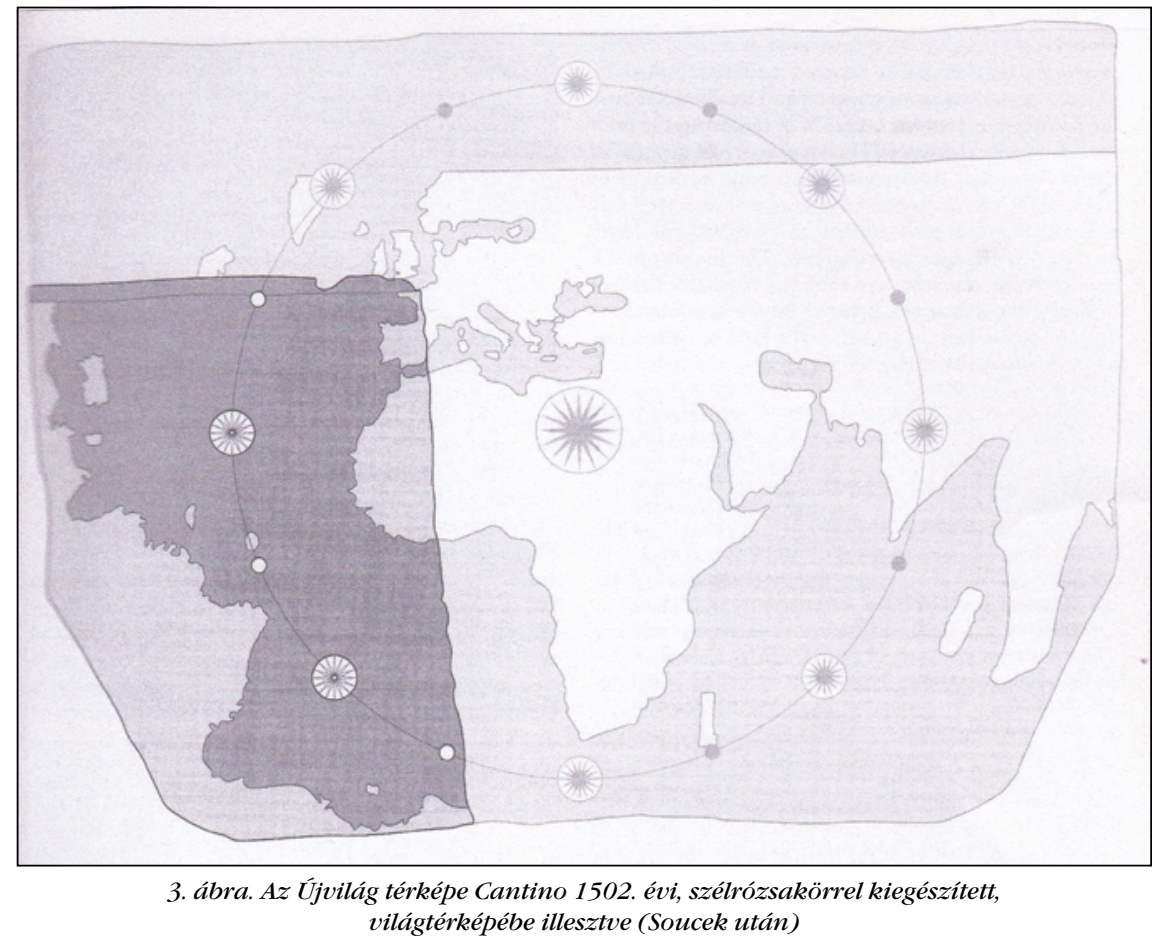

A térkép délkeleti sarkát az Újvilág térképéhez hasonlóan az ôzbốr alakjának megfelelốen rajzolták meg. Az északi résznél egy kiegészítő bőrdarab hozzáillesztését feltételezték. Keleten a lapszél levágja Ázsia egy részét. Hogy meddig terjedhetett a rajz, az továbbra is vita tárgya (Soucek 1992. p. 269.).

A térkép igazi érdekessége Amerika rajza. A lapszéli rajz mindjárt egy délkelet irányú kiszögelést alkot, majd tovább halad dél felé. A szárazföld délkeleti kiszögelése Kuba szigete lenne. Elôtte a nagyobb sziget Hispaniola. Hispaniolától délre Sanjuan-sziget. (Ezt

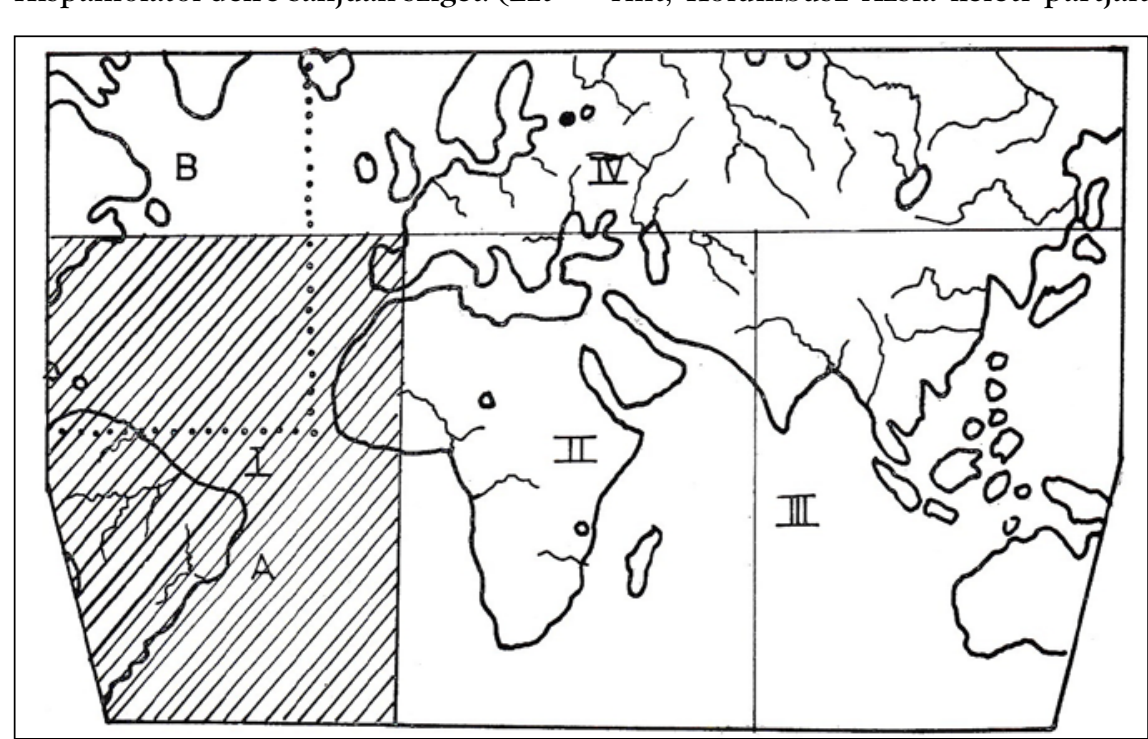

4. ábra. A világtérkép feltételezett szelvénybeosztása

Pirî Reis elsố világtérképének feltételezett alakja, a vonalkázott rész a fennmaradt térképrész. A pontozott vonal a második világtérkép megmaradt részét szemlélteti. (Afetinan után). a nevet San Juan Bautista, Keresztelő Szent János-sziget Kolumbusz adta a területnek, mai neve Puerto Rico). Ettől keletre a Virgin-szigetek, délkeletre a Kis-Antillák szigetsora látszik. A szigetvilág észak déli irányú rajza meglepô. Juan de la Cosa 1500. évi térképén Ázsia keleti partjaiba mélyesztett öbölbe, a valóságnak megfelelốen nyugat keleti irányban rajzolta meg a szigeteket. A szigetsor tájolása a Pirî Reis elôtti többi térképen is helyes. A furcsa déli tájolás lehetséges magyarázata az lehet, hogy Pirî Reis tudomása szerint, Kolumbusz Ázsia keleti partjait 
érte el. Ázsia keleti szélén, az akkor már ismert Japán-szigetek vonulata is nagyjából észak déli irányú. Pirî Reis feltételezhette, hogy a felfedezett szigetek e szigetsor tagjai. A szigetsor mögötti partvonal behorpadása után az Orinoco és az Amazonas torkolata jól kivehetô a térképen. Brazília kiszögellése után a térkép jelzi a La Plata széles torkolatát, majd a Túzföld ívét követve a Délisark körüli szárazföldet ábrázol. A partvonal Antarktisz felé való megrajzolása során Patagónia valamint a Tűzföld és az Antarktiszi-félsziget közötti tenger (Drake-átjáró) eltûnik.

A kor szokásának megfelelốen egykét fantázia által szült sziget is rákerült a térképre. Az Atlanti-óceán északi részén egy bálna rajza látható a hátán tûznél ételt készítô remetékkel. A rajz melletti leírás szerint ez a VI. századi ír szerzetes, Szent Brendan szigete. A szent az alvó bálnát szigetnek vélte. Mikor tüzet raktak, a bálna lemerült, és a szerzetesek csónakon menekültek. A térképkészítô pontosságra törekvését jelzi, hogy megjegyzi, az ábrázolt esemény nincs rajta a portugál térképeken, ókori térképrôl vette át.

A térkép eredeti, egyéni megoldása a szárazföld belsejébe (a térkép szélére) és a tenger felszínére írt, összesen 30 , hosszabb-rövidebb magyarázó szöveg. A szövegek nyelve, egyet kivéve, ottomán török. Egy megírás arab. Az arab nyelvú szöveg az Újvilág keletre nyúló tengeröblénél látható. A függólegesen elhelyezett megírás utal a szerzőre. „Ezt a térképet Pirî, Haji Mehmed fia, aki úgy ismert, mint Kemal Reis unokaöccse, rajzolta Gallipoliban (Geliboluban) 919. év muharram hónapjában" (azaz időszámításunk szerint 1513. március 9-e és április 7-e között). (Soucek 1992 p. 270.) A haji (hádzsi ejtésû) megírás azt mutatja, hogy apja az előírt időben (a muszlim vallás szerinti 12 holdhónapban) részt vett egy mekkai zarándoklaton.

A kolofonnak tekinthetô megjegyzés alatt hosszú leírás meséli el Kolumbusz és az új területek felfedezésének történetét, majd Pirî az általa szerkesztett térképrốl mesél. Senkinek sincs ilyen pontos világtérképe, állítja, majd leírja, hogy a szerkesztés során 20 térképet használt forrásként. A felhasznált világtérképek egyike Nagy Sándor korából való volt. Kilenc térképet arab, négyet portugál szerzôk készítettek. A portugál térképeknek matematikai vetületük volt. Végül megemlíti, hogy az egyik térképet Qul nb (Kolumbusz) személyesen rajzolta. Ezt a térképet nagybátyja Kemal Reis 1501-ben Valenciánál hét spanyol hajó elfoglalásakor, a hajón lévő személyzet több tagjával együtt szerezte meg, és így jutott hozzá Kolumbusz új felfedezéseket szemléltető (későbbi feltételezések szerint 1498-ban rajzolt) térképéhez. Az ütközet idején Pirî Reis is a hajón volt. A Kemal Reis fogságába került egyik matróz részt vett Kolumbusz elsố három amerikai útján, és ezekrôl részletesen beszámolt Kemal Reisnek. (Afetinan 1975. p. 28.). Az említett térképről Pirî Reis hivatkozásán kívül semmit nem tudunk. A kiváló földrajzi ismeretekkel rendelkezô elfogott egyszerú matróz története is eléggé hihetetlen. A térkép szerkesztésérôl szóló rész utolsó mondata: „A szerző a forrásként használt térképeket egy méretarányra hozva kapta a térkép végsố formáját, amelyik olyan pontos és valósághú, mint a török partokat szemléltető térképek." (Afetinan 1975. p. 32.)

A szöveg végén Pirî Reis a földrajzi nevekrôl ír. „A neveket, amelyekkel megjelöltük a szigeteket és a partokat, Kolumbusz adta, azért, hogy azok általuk legyenek ismertek.[...] Ezen a térképen a partok és a szigetek Kolumbusz térképérôl lettek átvéve." (Afetinan 1975. p. 31.). (Ez a megállapítás az amerikai területekre nézve igaz. Az afrikai partok mentén a portugál nevek mellett, Pirî Reis forrásainak megfelelôen, nagyon sok török elnevezés található.)

Hispaniola keleti oldalán lévô, északabbra esố szöveg, hivatkozás nélkül, az 1494. évi tordesillasi (a felfedezett és a felfedezendő területek Portugália és Spanyolország közötti megosztását szabályozó) megállapodást ismerteti. A térkép keleti szélén, az Afrika alatti leírás hiányos, a szöveg a térkép következô szelvényén folytatódhatott. Ez is jelzi, hogy egy nagyobb térképnek csak részlete maradt fenn.

A térkép különlegességének tartják, hogy a szárazföld mások által még nem ismert partvonalát délfelé meghosszabbítja, az évszázadokkal késôbb felfedezett Antarktiszig. A térkép, már ismertetett leírása szerint, Pirî Reis a térkép összeállításánál Nagy Sándor korából való térképet is felhasznált. Ez feltehetốn Ptolemaiosz térképe lehetett. Ptolemaiosz térképein, az óceánokat délrôl lezáró földrészt ábrázolt. Pirî átvehette ezt az elképzelést Ptolemaiosztól, ezért rajzolta tovább a partvonalat.

A térkép Amerikát ábrázoló részei, kisebb eltérésektôl eltekintve, Juan Díaz de Solís és Vicente Yáñez Pinzón 1508-1509. évi útjai előtt felfedezett területeket mutatják, azaz olyan területeket is ábrázolnak, amelyeket egyéb leírások még nem tartalmaztak. Nem tudjuk milyen forrásokból jutott Pirî ezekhez az információkhoz, honnan szerzett tudomást például az elsônek ábrázolt, La Plata-torkolat létezésérôl és Kolumbusz negyedik (1502-1504) útja és a térképen ábrázolt 1508. év közötti időszak felfedezéseirôl.

Pirî Reis 1528-ban még egy világtérképet készített. Ez a térkép is az isztambuli szultáni palotából került elô. Ezen is szerepel, kis változtatással az a szerzôrôl szóló szöveg, amelyik az 1513. évi térképen olvasható. „Ezt a térképet az alázatos Pirî, a néhai Haji Mehmed fia, aki úgy ismert, mint Kemal Reis apai unokaöccse, rajzolta Gallipoliban 1528ban. Ez az Ô munkája." (McIntosh 2015 p. 315.)

A sors játéka, hogy e világtérképének is csak egy részlete, az Észak-és KözépAmerikát ábrázoló része maradt fenn. (4. ábra) A tevebôrre rajzolt rész nagysága $69 \times 70 \mathrm{~cm}$. Az elôző térkép északdéli irányba fordított szigetsorát már helyesen ábrázolja a térkép. A vetületben való gondolkodás elsô jeleként, Kuba déli végét átszelve, megjelenik a Ráktérítô vonala. Újonnan felfedezett területenként feltűnik Grönland, Labrador, Új-Skócia, Florida, Honduras és a Yucatán-félsziget partvonala. A térképen csak egy-két megírás van. A Grönlandnál lévô azt állítja, hogy azt a portugálok fedezték fel. A KözépAmerikánál lévô szöveg Balboa földszorost átszelô útjára utal (Harley Woodward 1992).

\section{Merész elképzelések Pirî Amerika-térképének az eredetéról}

Dél-Amerika érdekes homorú alakja, a partvonal Antarktiszig húzódó vonala 


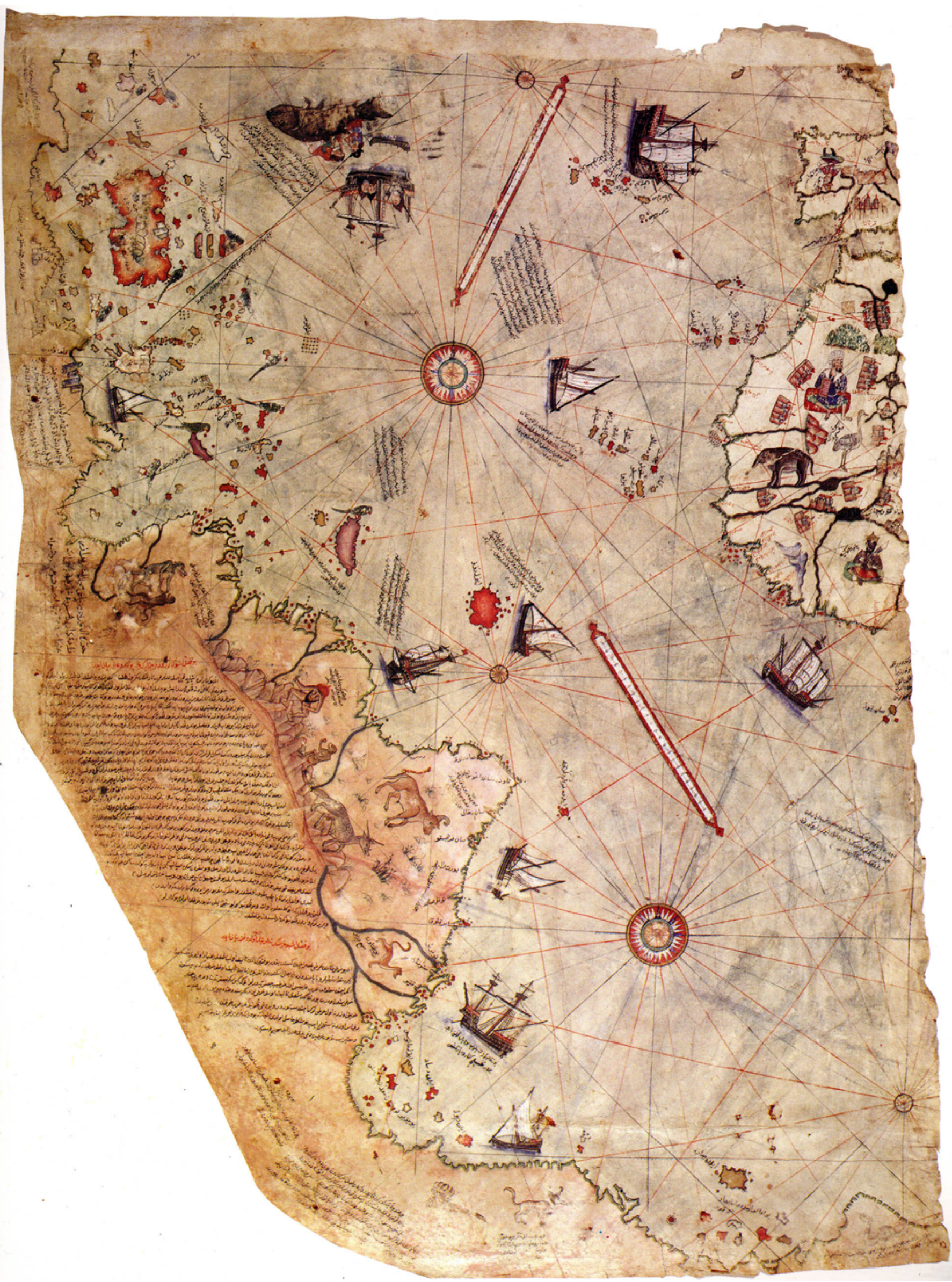

5. ábra. A világtérkép Amerikát ábrázoló része 
nyomán Hapgood feltételezte, hogy a térképnek van vetülete, mégpedig Kairó középpontú egyenlô foktávolságú azimutális vetület. A vetület sajátságából adódik Dél-Amerika furcsa elcsavarodott alakja. A vetületbe rajzolt térkép, szerinte két évszázaddal a kronométer feltalálása elôtt, pontos hosszúsági adatokat mutat (Hapgood, 1979).

Däniken a vetületből adódó elrajzolás elméletét tovább fejlesztette. Szerinte Földön kívüli lények Kairó felett készített felvétele a térkép alapja. A gömb alakú Föld rajza jelentkezik az úrfényképen olyan csavart formában, mint Pirî Reis térképén (Däniken 1990). A fantasztikus ötlet rendkívül gyorsan és széles körben elterjedt és talán napjaink legismertebb térképévé tette Pirî Reis munkáját.

A két, széles körben ismert szerzô munkái mellett, nagyon sok egyéb tanulmány foglalkozik Pirî Reis 1513. évi Amerika-térképével. Van szerzô, aki szerint korai kínai felfedezôk eredményeit szemlélteti, egy másik elmélet szerint a paleolitkori, 80 méterrel alacsonyabb tengerszintnél látható partvonalat mutatja, természetesen ósemberek egykori rajzai alapján (Papp-Váry 2005).

\section{Befejezó gondolatok}

Pirî Reis életútját könyvében közölt önéletrajza alapján 1526-ig tudjuk követni. Élete további folyására, majdnem három évtized eseményeire, munkájára, csak néhány hivatalos papírból következtehetünk. Eszerint 1547-ben a Déli-tengerek (Vörös- és Arab-tenger,
Indiai-óceán) hajóhadának lett a beglerbégje (admirálisa). A következô évben visszafoglalta Ádent és Maszkat városát a portugáloktól. 1553-ban a Perzsa-öböl bejáratánál (ma Irán partjai elôtt) lévố Hormuz-szigetrôl akarta elûzni a portugálokat. Az ostrom közben kapta a hírt, hogy az Indiai-óceán felôl felmentô portugál hajóhad közeledik. Meggyengült egységével az öböl végén fekvô Baszrába hajózott. A török parancsnok jelentéktelen ürüggyel nem engedte be a városba. Megmaradt három hajójával, mieloótt a portugálok lezárnák a Hormuzi-szorost, viszszavonult Szuezbe. Az ütközet elkerülése miatt, a baszrai parancsnok vádjai alapján, halálra ítélték. Az ítéletet 1554ben, Egyiptomban hajtották végre. Ha 1465-ben született, akkor már közel járt a kilencvenedik életévéhez, ha csak 1470-ben született, akkor is már 84 éves volt.

Pirî Reis életrajzi leírásán kívül világtérképeiről, hajózást segítő könyvéről korabeli elismeréseket nem ismerünk, pedig állítása szerint világtérképét két szultán is látta, a hajózásról szóló könyvét is megkapta a kivégzése évében is uralkodó I. Szulejmán szultán. Fennmaradt hajózási térképei, a Török Birodalom összeomlása után elôkerült világtérképének maradványai igazolják térképkészítô munkásságát. Nincs okunk azt hinni, hogy élete egyéb eseményeit nem a valóságnak megfelelően írta le. Feltételezhetjük, hogy tudósként kora nem ismerte el. Kivégzése is ezt támasztja alá. Elfogadott, tudományos munkássága valószínúleg mentség lehetett volna az ítéletet hozók előtt.

\section{Irodalom}

Afetinan, A. 1975. Life and Works of Pirî reis. The Oldest Map of America. Turkish Historical Society, Ankara. 88 pp., LIX maps.

Akçura, Y. 1935. Piri Reis Haritası hakkında izahnâme - Die Karte des Piri Reis Piri Reis Map - Carte de Piri Reis. T. T. K. Yayinlari, No. 1. İstanbul.

Bagrow, L. 1985. History of Cartography. Revised and Enlarged by R. A. Skelton. Precedent Publishing Inc., Chicago. $312 \mathrm{pp}$.

Brice, W. - Imber, C. 1978. Turkish Charts in the Portolan Style, The Geographical Journal, 144 (1978), pp. 528-29.

Däniken, E. von 1990. A jövố emlékei, Háttér Kiadó, Budapest. 142 pp.

Hapgood, C. H. 1979. Maps of the ancient seakings: evidence of advanced civilization in the ice age. Dutton, New York. 276 pp.

Harley, J. B. - Woodward, D. 1992. The History of Cartography, vol. 2, book 1. Cartography in the Traditional Islamic and South Asian Societies. The University of Chicago Press, Chicago/London. 579 pp.

McIntosh, G. C. 2015. The Piri Reis Map of 1528: A comparative study with other maps of the time. Mediterranea-Riserche Storiche, Volume 12, pp. 303-318.

Papp-Váry Á. 2005. Egy térképészeti rejtély: Piri Reis Dél-Amerika térképe. Földrajzi Közlemények 129. évf. 3-4. sz. pp. 177-187.

Soucek, S. 1992. Islamic Charting of the Mediterranean, In Harley, J.B. - Woodward, D. (ed.): The History of Cartography, vol. 2, book 1. Cartography in the Traditional Islamic and South Asian Societies. The University of Chicago Press. Chicago/ London. pp. 263-92.

Zaimeche, S. 2010. Piri Reis: A Genius 16th-century Ottoman Cartographer and Navigator. https://muslimheritage.com/ piri-reis-16th-c-cartographer-navigator/

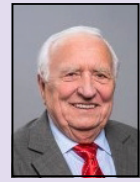

Dr. Papp-Váry Árpád professor emeritus

Budapesti Metropolitan Egyetem pappvary@t-online.hu 